症 例

左上葉管状切除を要した気管支内腔進展を伴う術後再発胸腺腫の一例

\author{
吉田美由紀, 宮原＼cjkstart聡, 山本玲央那 \\ 佐藤 寿彦, 白石 武史, 岩㠃 昭憲
}

\begin{abstract}
要旨
胸腺腫は，心膜や肺などの近接蔵器への直接浸潤がしばしば認められるが，気管支内腔を中枢に向かって進展することは まれである，今回我々は，胸腺腫術後 11 年で左上葉部分切除断端に再発を認め, 気管支内腔進展を来したことから, 左上葉 管状切除を必要とした症例を経験した. 59 歳男性で, 11 年前に他院で胸腺腫 type B3 に対して胸腺・胸腺腫摘出術, 左上葉 部分切除術および横隔神経合併切除を施行された。咳嗽を主訴に近医を受診し左上葉の $8 \mathrm{~cm}$ 大の腫瘤を指摘され，原発性肺 癌の疑いで当科紹介となった，左上葉気管支はポリープ状の腫瘍により閉塞し，気管支鏡生検では診断が付かず，診断と治 療のために左上葉切除を行った，術中迅速病理検査で胸腺腫再発と診断され，上葉気管支断端が陽性であったことから管状 切除を行い，換気後に肺動脈の屈曲を認めたために肺動脈形成を追加した.
\end{abstract}

索引用語 : 胸腺腫, 気管支内進展, 術後再発, 肺葉切除

thymoma, endobronchial extension, postoperative recurrence, lobectomy

\section{はじめに}

胸腺腫は前縦隔に発生する全腫瘍の約 40\%であり, 周 囲臟器への浸潤が比較的多くみられる type B3 は $80 \%$ 以上に直接浸潤を来すとも報告されて いるが, 完全切除が可能であった症例では 5 年生存率は $60 \%, 10$ 年生存率は $40 \%$ と予後は比較的良好である ${ }^{2)}$. しかし術後 10 年目以降の再発も比較的多く報告されて おり，長期のフォローアップが必要である。 今回, 術後 11 年で局所再発を来し, 気管支内進展を伴った胸腺腫の 再発症例を報告する。

\section{症例}

59 歳男性. 11 年前に胸腺腫 type B3 に対して胸骨正中 切開で胸腺・胸腺腫摘出術, 左上葉部分切除および横隔 神経合併切除を施行された，術後の化学療法や放射線療 法は施行されず, 外来で 1 年間は経過観察されていたが,

福岡大学呼吸器乳腺内分泌小児外科

原稿受付 2019年11月14日

原稿採択 2020年 4 月 22 日
その後は自己中断されていた，持続する咳嗽を主訴に近 医を受診し, 胸部 CT で左上葉縦隔側に, 前回手術時の久 テイプラーに接し, $8 \mathrm{~cm}$ 大の腫瘤があり, PET 検査で異 常集積（SUV max 9.47）を認めた（Fig. 1)。気管支鏡検 査では左上葉気管支から突出するポリープ状の腫瘤性病 変を認めた (Fig. 2). ポリープ状の腫瘍先端から生検を行 われたが壊死性病変の診断であり, 診断と治療の目的で 当科紹介となった．画像所見と既往から胸腺腫の再発と 判断したが，気管支鏡所見からは原発性肺癌を鑑別にあ げ，診断と治療の目的で左上葉切除を予定した，胸骨正 中切開の既往から胸骨裏面および胸腔内の癒着が予想さ れ，また胸骨正中切開では得ることが難しい側方の視野 を確保できる clamshell 開胸を選択した.

手術所見：開胸に際して,内胸動静脈の切離が必要に なってくることから, 胸骨裏面の癒着剥離を側方から慎 重に行った，腫瘍は左上葉内に存在しており，縦隔脂肪 組織と一塊になっていたが心膜浸潤はなく, 胸水や播種 病変は認めなかった。 上肺静脈を露出, テーピングし, 左主肺動脈をテーピングした後に A3 根部の剥離を慎重 に行った。浸潤が疑われていたが鋭的に剥離できた。葉 間を作成しながら A4-5 を結紮切離し, 上肺静脈を切離, 


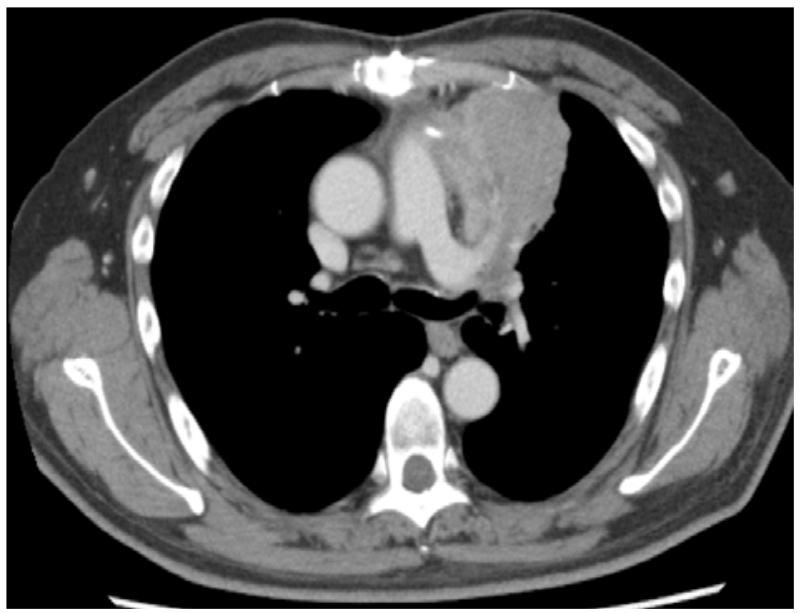

Fig. 1 Chest computed tomography showing a mass in the left upper lobe of the lung. The tumor obstructed the bronchus of the left upper lobe.

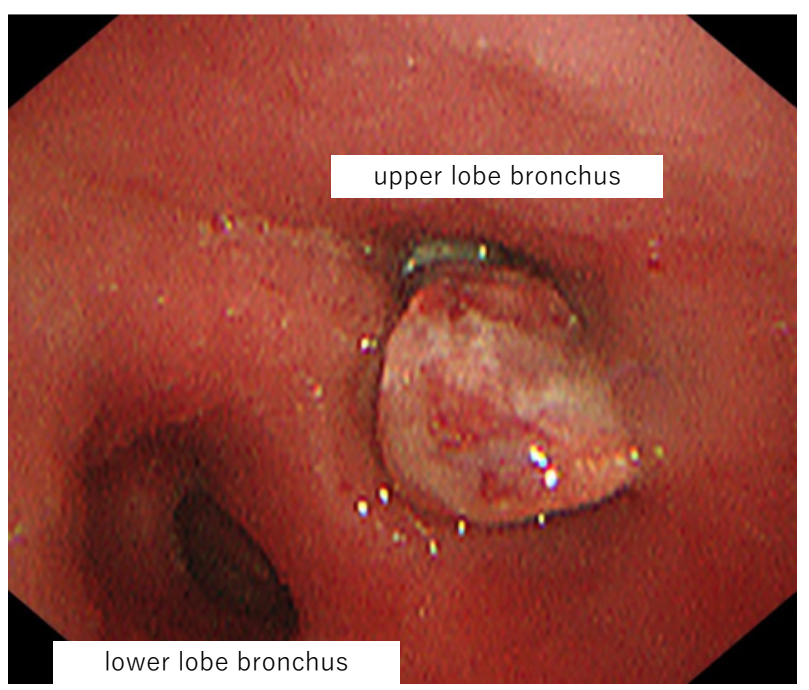

Fig. 2 Bronchoscopy revealed complete obstruction of the left upper bronchus by a polypoid tumor.

上葉気管支をメスで切開すると, 上葉気管支内腔にはポ リープ状に腫瘍が発育していた，上葉気管支断端を術中 迅速に提出した. 最後に $\mathrm{A} 1+2$ の枝を順次結紮切離し左 上葉切除を完了した．術中迅速の結果は胸腺腫の診断で あり，断端の気管支壁にも腫瘍が残存していたため, 左 上葉気管支分岐部を管状に切離し気管支形成を行った。 換気後, 肺の拡張に伴い左主肺動脈が屈曲し血流障害を 認めたために, 屈曲部を切除し肺動脈形成を行った.

切除病理標本所見: $5.0 \times 5.0 \times 3.5 \mathrm{~cm}$ 大の肉眼的に肺 内の多結節性病変が集簇していた. 組織学的に好酸性で

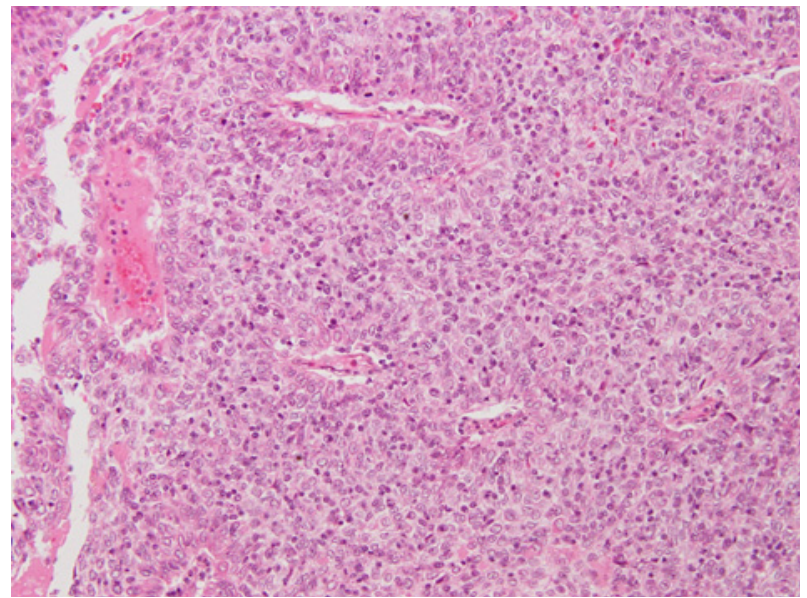

Fig. 3 Hematoxylin-eosin staining. Magnified image $(\times$ 100) of the tumor, showing features of a type B3 thymoma as described according to the World Health Organization (WHO) classification. The tumor was composed of round and polygonal cells with lymphocytic infiltrations.

境界不明瞭な細胞質と円形から類円形核を有する腫瘍性 上皮細胞が胞巣状あるいはシート状に増殖し，血管周囲 腔が散見され，核分裂像もみられた。腫瘍性上皮細胞間 には小型リンパ球の混在が認められ，免疫学的組織所見 と併せて胸腺腫 type B3 と診断された(Fig. 3).一部縦隔 脂肪組織への浸潤を認めた。気管支内のポリープ状の腫 瘍も肺内病変と同様に高度の壊死を伴う腫瘍細胞集塊が 認められ, 再発胸腺腫の気管支進展が確認された。術後 経過は良好で,リハビリ目的に術後 22 日目に転院となっ た. 術後 1 年が経過するが, 再発は認められていない.

\section{考察}

本症例は肺および横隔神経浸潤を伴う胸腺腫 type B3 に対して左上葉部分合併切除が行われ，その切除断端に 再発したと思われる症例であったが，気管支に沿って進 展し内腔にポリープ状に発育する, まれな進展形式で あったために報告した。

胸腺腫は卵円形および紡錘形腫瘍性上皮細胞からなる type A と類円形および多角腫瘍性上皮細胞からなる type B，それらが混在する type $\mathrm{AB}$ に分けられ，さらに type B は腫瘍性上皮細胞の異型とリンパ球浸潤の程度 により type B1, B2, B3 に分類され ${ }^{3)}$ ，それぞれの割合は type A : 6\%, type AB :28\%, type B1 : 20\%, type B2 : $35.5 \%$, type B3 : 10.5\% と報告されている2). その type 
により周囲組織への浸潤の程度が異なっており, type A で11.1-23.8\%, type AB で 41.6-51\%, type B1 で 47.373.3\%, type B2 で 69.1-82\%, type B3 で 84.6-100\% であっ た ${ }^{2,4,5)}$. 胸腺腫 type B3 は浸潤という意味で悪性度の高い 腫瘍と考えられ, 術後再発率も他の type に比べて $28.6 \%$ と高い(type A : 0\%, type AB : 4.5\%, type B1 : 8.5\%, type B2 : 18.1\% ${ }^{2)}$. 本症例も type B3 であり, 初回手術 時に胸膜，肺，横隔神経への浸潤が認められ合併切除さ れたが局所再発を来した．胸腺腫は遠隔期での再発も比 較的多く報告されており $り^{1.6)}$ ，長期経過観察が必要と考え られるが，外来通院を自己中断され再発病変が大きく なってからの手術となったことが，気管支管状切除を余 儀なくされた原因と考えられる。

本症例は胸腺腫術後であり, 前回手術時のステイプ ラー近傍に腫瘍が存在していたことから胸腺腫の再発を 第一に考えたが, 気管支鏡, CT 画像からは左上区の気管 支にポリープ状に発育する腫瘍であり，左上葉原発性肺 癌の可能性を術前に否定し得なかった。過去に胸腺腫が 気管支内進展を認めたという報告は 29 例あり, その組織 型は type B2 が最も多く, 次いで type B3, type AB, type B1, type Aの順であり, 周囲臟器浸潤の割合とは若干異 なった傾向であった，再発形式としての気管支内進展の 報告は 8 例であった。うち 5 例は放射線治療歴があ $り^{7-10)}$, 放射線治療により照射野の胸膜・肺・末梢気管支 が脆弱になり侵入しやすくなった可能性が示唆されてい る ${ }^{9)}$. 本症例では初回手術後に放射線治療は行われておら ず，この機序には該当しない．単独手術後の再発は 3 例 報告されており ${ }^{11,12)}, 2$ 例は術後肺内転移病巣が気管支内 へ進展していた．本症例のように断端再発からの気管支 内進展と思われる報告は 1 例のみであったが，いずれも 術前治療は行われておらず，肺転移病変近傍あるいは切 除断端の比較的大きな末梢気管支から腫瘍細胞が侵入 し, 中枢へ沿って進展したものと考えられる。これら 8 例の再発に対してはプラチナ製郕を中心とした化学療法 あるいは放射線照射が行われているが，再手術を行った 報告はなかった. 本症例では, 左上葉切除と左上葉気管 支の管状切除で完全切除が達成できること，遠隔転移が なかったことから手術を選択した. 完全切除が再発胸腺

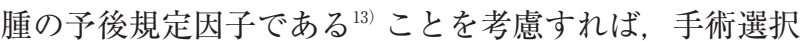
は妥当と考える.

胸腺腫の気管支内進展では気管支内の腫瘍先進部は壊 死組織を伴い，気管支鏡で診断が付かず，最終的に手術
を選択される報告も多い。これは腫瘍により圧迫された 気管支粘膜が壊死しながら進展することや，肺癌などの ように気管支粘膜表面に浸潤した腫瘍細胞が壊死するこ となどが考えられているが詳細は定かではない，本症例 でも気管支鏡で得られた組織は壊死組織のみであり，術 前に診断を確定することは困難であった，胸腺腫治療後 の症例では，その既往から診断を推察することは可能で あるが，これまでの報告の中には複数回の気管支鏡生検 を必要としたものや，開胸生検を選択されたものもあっ た. 真菌感染を合併していた報告もあり ${ }^{10,11)}$ ，壊死組織や 炎症細胞浸潤といった所見の解釈には注意が必要であ る.

\section{結語}

気管支内進展を伴う再発胸腺腫の症例を経験した。ま れな発育形態であり，進展先進部は壊死を伴うという特 徵を有していたため, 術前の気管支鏡検査では確定診断 を得られなかった，胸腺腫がこのような進展形式を取る ことを認識し, 合併切除の際には十分な切除距離を確保 することが必要である。また，注意深い長期の経過観察 を行い，胸腺腫再発時には手術も検討の余地があると思 われる。

\section{利 益相反}

本論文について申告する利益相反はない.

\section{文献}

1. Lewis JE, Wick MR, Scheithauer BW, Bernatz PE, Taylor WF. Thymoma. A clinicopathologic review. Cancer 1987: 60: 2727-43.

2. Okumura M, Ohta M, Tateyama H, Nakagawa K, Matsumura A, Maeda H, et al. The World Health Organization histologic classification system reflects the oncologic behavior of thymoma: a clinical study of 273 patients. Cancer 2002; 94: 624-32.

3. Marx A, Chan JK, Coindre JM, Detterbeck F, Girard N, Harris NL, et al. The 2015 World Health Organization classification of tumors of the thymus: continuity and changes. J Thorac Oncol 2015; 10: 1383-95.

4. Rena O, Papalia E, Maggi G, Oliaro A, Ruffini E, Filosso $\mathrm{P}$, et al. World Health Organization histologic classification: an independent prognostic factor in resected thy- 
momas. Lung Cancer 2005; 50: 59-66.

5. Kondo K, Monden Y. Therapy for thymic epithelial tumors: a clinical study of 1,320 patients from Japan. Ann Thorac Surg 2003; 76: 878-85.

6. Hamaji M, Allen MS, Cassivi SD, Nichols FC $3^{\text {rd }}$, Wigle DA, Deschamps C, et al. The role of surgical management in recurrent thymic tumors. Ann Thorac Surg 2012; 94: 247-54.

7. Matsuguma H, Furuta M, Tsukiyama I, Kamiya N, Sawafuji M, Yokoi K. Endobronchial brachytherapy for recurrent thymoma showing endobronchial polypoid growth. Am J Clin Oncol 1999; 22: 84-6.

8. 片野拓馬, 池田 慧, 磯本晃佑, 関根朗雅, 萩原恵理, 小 倉高志. 放射線治療後に気管支内腔進展した浸潤性胸腺 腫の 2 例. 日呼吸誌 2018; 7: 100-4.

9. Honda T, Hayasaka M, Hachiya T, Hirose Y, Kubo K,
Katsuyama T. Invasive thymoma with hypogammaglobulinemia spreading within the bronchial lumen. Respiration 1995; 62: 294-6.

10. 安孫子正美, 佐藤 徹, 塩野知志, 高橋伸政, 金内直樹, 塚本東明, 他. 気管支内腔へポリープ状に発育進展した浸 潤性胸腺腫の 1 例. 気管支学 1999; 21: 289-93.

11. 米田太郎, 卯尾真由加, 木場隼人, 酒井珠美, 上田善道, 笠原寿郎. 気管支内腔に進展した術後再発浸潤性胸腺腫 の 2 例. 肺癌 2014; 54: 191-8.

12. 野津田泰嗣, 桜田 晃, 遠藤千顕, 岡田克典, 近藤 丘. 気管支内にポリープ状転移病巣を形成した胸腺腫の 1 例. 気管支学 $2015 ; 37$ : 82-6.

13. Marulli G, Margaritora S, Lucchi M, Cardillo G, Granone P, Mussi A, et al. Surgical treatment of recurrent thymoma: is it worthwhile? Eur J Cardiothorac Surg 2016; 49: $327-32$.

\title{
Surgical treatment of endobronchial extension in a patient with recurrent thymoma using sleeve lobectomy
}

\author{
Miyuki Yoshida, So Miyahara, Leona Yamamoto \\ Toshihiko Sato, Takeshi Shiraishi, Akinori Iwasaki \\ Department of General Thoracic, Breast and Pediatric Surgery, \\ Fukuoka University School of Medicine and Hospital, Fukuoka, Japan
}

The endobronchial extension of thymoma is extremely rare. Herein, we report a recurrent thymoma patient with endobronchial polypoid growth. A 59-year-old man, with a past history of extended thymectomy for a type B3 thymoma with partial resection of the left upper lobe and combined resection of the left phrenic nerve, presented to a hospital with a chief complaint of cough. Chest computed tomography revealed an ill-defined mass in the left upper lobe of the lung. An endobronchial polypoid tumor occupying the bronchus of the left upper lobe was detected by bronchoscopy. Although biopsies were performed, definite evidence of malignant tumor cells could not be confirmed. He was referred to our hospital for surgery with a suspicion of primary lung cancer. During the surgery, a large tumor was located in the left upper lobe. Evaluation of intraoperative frozen sections of the tumor was suggestive of thymoma, and the left upper bronchial stump was positive for tumor cells. We performed left upper lobe sleeve lobectomy along with pulmonary artery reconstruction to correct a kink in the left main pulmonary artery. He was discharged from the hospital on postoperative day (POD) 22 after surgery with instructions for continued rehabilitation.

(C) The Japanese Association for Chest Surgery (JACS) 